Jurnal Pendidikan Universitas Garut

Fakultas Pendidikan Islam dan Keguruan

Universitas Garut

ISSN: $1907-932 \mathrm{X}$

\title{
Revitalisasi Permainan Tradisional Sebagai Wahana Peredam Permainan Digital Pada Anak
}

\author{
Azhar Ramadhana Sonjaya, Z.Arifin, Riri Agustia Pratiwi \\ Fakultas Pendidikan Islam dan Keguruan, \\ Program Studi Pendidikan Jasmani Universitas Garut \\ a.sonjaya.pjkr@uniga.ac.id
}

\begin{abstract}
Abstrak
Tujuan utama dalam merevitalisasi permainan tradisional saat ini adalah mempertahankan identitas suatu negara terhadap ciri khas sebuah permainan tradisional yang berkembang disetiap daerah dalam Negara Kesatuan Republik Indonesia. Perspektif yang perlu kita cermati adalah bahwa kemajuan teknologi tidak seluruhnya membawa akibat positif bagi kita, hal ini tentu mengkhawatirkan terutama bagi anak-anak yang sedang mengalami fase perkembangan serta mencari identitas diri. Pendekatan revitalisasi dalam penelitian ini menekankan pada pengenalan dan penerapan berbagai macam ragam, manfaat permainan tradisional yang diberikan kepada anak-anak. Metode ini bertujuan untuk menggerakkan kembali permainan tradisional, menanamkan nilai-nilai budaya serta melatih anak untuk memiliki sikap yang berkarakter. Asosiasi Penyelenggara Jasa Internet Indonesia (APJII) mencatat salah satu bentuk hiburan yang banyak dipilih masyarakat di masa pandemi Covid-19 adalah bermain game online sebesar 16,5 persen. Sementera musik online 15,3 persen. Sehingga perkembangan permainan digital tidak diimbangi dengan penerapan permainan tradisional disetiap daerah terutama daerah provinsi Jawa Barat. Oleh karena itu pembahasan dalam penelitian ini adalah menyajikan kajian ilmiah tentang revitalisasi permainan tradisional sebagai wahana peredam permainan digital pada anak dengan harapan anak-anak dapat terus memainkan permainan tradisional di daerah nya.
\end{abstract}

Kata kunci: permainan tradisional, game online

\section{Pendahuluan}

Indonesia dikenal sebagai negara yang mempunyai ragam suku, agama, ras, dan budaya yang berbeda beda, indonesia menjadi suatu negara dengan tinggkat toleransi yang tinggi. permainan-permainan tradisional yang terlahir dari budaya masyarakat indonesia yang saat ini mulai hilang tergerus zaman. Dengan adanya teknologi yang mulai menjamur di masyarakat saat ini, permainan tradisional mulai tidak terjamah lagi oleh anak-anak kecil dilingkungan kita. Jenis permainan rakyat (permainan 
anak) dapat mengembangkan potensi kecerdasan jamak, seperti kecerdasan linguistik, kecerdasan logika, kecerdasan visual-spasial, kecerdasan kinestetik tubuh, kecerdasan musik, kecerdasan interpersonal. Kegiatan bermain dapat mengangkat nilai-nilai budaya melalui permainan tradisional menjadikan anak kreatif, sebagai sebuah terapi bagi anak-anak untuk melepaskan emosinya dengan berteriak, tertawa, dan bergerak (Disbudpar DK1, 2011: 4). Dalam kaulinan atau permainan tradisional (Sunda), ada banyak maksud dan tujuan yang hendak dicapai. Intinya mencari kesenangan bersama-sama. Bukan kesenangan individual sebagaimana yang diciptakan dalam permainan modern yang elektronis bersifat individual seperti Play Station dan aplikasi game online yang terdapat pada play store. Permainan elektronis mengajarkan anak menjadi tidak terikat atau mahardika atau independen.

Sebaliknya, masyarakat Sunda telah banyak mengenal jenis banyak permainan yang melibatkan kelompok yang mengajarkan anak hidup sauyunan (kebersamaan) kreatif, tegas dan cerdik. ada banyak jenis kaulinan dan permainan yang memiliki istilah atau penamaan sama, namun istilah yang dipergunakan untuk perintah, aturan maupun ungkapan tiap daerah berbeda satu dengan lainnya. keragaman bahasa ini selain disebabkan oleh penutur yang tidak homogen, terjadi juga karena kegiatan interaksi sosial yang sangat beragam. Hal ini menunjukan kekayaan suku Sunda dari suku lainnya di tanah Jawa maupun di tanah air. Tidak terkecuali dalam kegiatan bermain. Masih ada satu tahapan lagi yakni pengembangan dan ini membutuhkan kerjasama pelaku pendidikan. Semestinya, ada ada satu tempat untuk pembelajaran mainan tradisional di dalam kurikulum (Alif, Sachari, \& Sabana, 2015).

Permainan tradisional dianggap istimewa karena ada hal-hal yang membedakannya dengan permainan modern yang sedang berkembangan saat ini. Jika kita mampu lebih menelaah permainan tradisional, maka akan kita jumpai nilai-nilai permainan yang sangat menarik dan tentunya sangat baik untuk perkembangan karakter anak (Yudiwinata \& Handoyo, 2014). Padahal, filosofi yang disampaikan dalam kaulinan atau permainan anak adalah memperkenalkan dua sifat berupa baik dan buruknya. Anak dengan sendirinya ditantang belajar dan mengenal dengan dunianya supaya kedepannya generasi mendatang menjadi generasi yang mahardika, kompetitif, kreatif, cerdik, memilik rasa sosial, kebersamaan dan pendidikan rasa yang didalamnya memiliki nilai etis, religius dan filosopis (disparbud Jawa Barat, 2016).

Perkembangan teknologi pada saat ini menutup eksistensi permainan olahraga tradisional disetiap daerah, usia dini hingga dewasa lebih menikmati permainan dengan bentuk digital yang disebut game online, suatu permainan yang dapat diakses oleh banyak pemain, dimana mesin - mesin yang digunakan pemain dihubungkan oleh jaringan internet. Game online mempunyai beberapa daya tarik yang membuat para siswa lebih senang bermain ketimbang belajar. Aktivitas bermain game online sudah menjadi rutinitas setiap hari. Selain permainan yang menarik, game online juga dapat menyebabkan ketagihan karena ketika sedang bermain kemudian kalah akan mencoba kembali supaya menang. Dalam sudut pandang sosiologi, jika pelajar sudah 
kecanduan pada game online maka cenderung akan memiliki sifat egosentris dan akan mengedepankan sifat idividualisnya. Siswa dengan sendirinya akan menjauh dari lingkungan sekitar dan akan beranggapan bahwa lingkungan sosial adalah tempat untuk bermain game dan kehidupannya adalah di dunia maya, sehingga game online berdampak negatif bagi motivasi belajar para siswa. Seorang anak yang sudah kecanduan game online akan mempengaruhi motivasi dalam belajarnya dan jika motivasi belajarnya terganggu maka akan mempengaruhi pula prestasi belajarnya, seseorang yang sudah kecanduan game online membutuhkan penanganan khusus (Nisrinafatin, 2020).

Namun kondisi saat ini sebagaimana yang terjadi dalam hubungan sosial, berbagai aktivitas selalu dikaitkan dengan prestasi yang pada akhirnya harus ada pemenang. Tidak terkecuali dengan permainan atau kaulinan anak, padahal inti dan tujuan dari permainan adalah kesenangan, meski harus diakhiri ada yang kalah dan menang. Selain tujuan akhir dari permainan, atau kaulinan yang sudah mulai keluar dari nilai filosofi Sunda sesungguhnya yang tidak mengenal kompetisi, kaulinan saat ini lebih diarahkan pada kompetisi olahraga. Zaini Alif dalam bukunya yang berjudul mainan dan permainan tradisional Sunda mengatakan bahwa setiap mainan dan permainan anak, melatih anak bermain melalui aturan dan sistem untuk patuh pada permainan dan mainan itu sendiri. Patuh adalah hal yang paling mendasar dalam pelaksanaannya sebuah permainan, tanpa tunduk dan patuh pada aturan dan sistem sebuah permainan, mustahil permainan itu dapat dilaksanakan (2014:3). Selain itu, mainan dan permainan juga secara langsung mengajarkan nila-nilai toleransi, kejujuran, kepemimpinan, strategi, kerjasama dan tanggungjawab.

\section{Metodologi Penelitian}

Penelitian ini menggunakan metode penelitian pustaka. Menurut Nazir (1988:111) studi kepustakaan adalah teknik pengumpulan data dengan mengadakan studi penelaahan terhadap buku-buku, literatur-literatur, catatan -catatan yang ada hubungannya dengan masalah yang dipecahkan. Penelitian ini mengkaji mengenai pengaruh game online terhadap motivasi belajar siswa.

Analisis data yang digunakan dalam penelitian yaitu dikalukan dengan cara reduksi data, display data, dan gambaran kesimpulan. Sehingga mendapat kesimpulan untuk penelitian ini. Teknik pengumpulan data dengan cara membaca dan mencatat informasi - informasi penting yang terdapat di berbagai jurnal yang terkait dengan penelitian yang sedang dilakukan.

\section{Pembahasan}

Beberapa cara untuk merevitalisasi permainan tradisional dengan melakukan penerapan permainan tradisional melalui penerapan metode demonstrasi dalam permainan tradisional magoak-goakan di Bali (Putu Winda Suyeni ${ }^{1}$, I Nyoman Wirya ${ }^{2}$, 2016) dari penelitian tersebut dijelaskan bahwa permainan tradisional dapat diterapkan melalui metode demonstrasi dengan jenis permainan nya adalah magoakgoakan sehingga dapat meningkatkan kemampuan kerjasama anak TK Widya Sesana 
Sangsit tahun pelajaran 2015/2016. Identifikasi lain terhadap faktor-faktor permainan tradisional lainnya adalah bebentengan sebagai basis perancangan game pemicu peningkatan sistem motorik anak (Irfansyah, 2013) sehingga permainan bebentengan merupakan gerakan pada kategori aktivitas di atas ambang batas (sedentary behavior) yaitu suatu aktivitas gerak berpindah posisi pemain seperti berjalan dan berlari kea rah benteng serta mengejar dan menghindar lawan maka permainan bebentengan mampu memotivasi anak-anak dalam bermain bebentengan dan dapat bersentuhan langsung sebagai point utama pada permainan bebentengan. Permainan tradisional dalam budaya dan perkembangan anak (Yudiwinata \& Handoyo, 2014), terdapat hasil yang signifikan terhadap aktivitas anak-anak yang melakukan permainan tradisional dan anak-anak yang melakukan permainan modern terdapat pengaruh terhadap perkembangan motorik dan kognitif seorang anak, disebutkan bahwa hasilnya adalah anak yang melakukan permainan tradisional jauh lebih berkembang kemampuan motorik dan karakternya serta peran orang tua dan guru sangat penting sebagai bentuk pelestarian permainan tradisonal yang terkandung dalam budaya dan tradisi masyarakat Indonesia. Pengembangan permainan tradisional ekar mix dalam pembelajaran penjasorkes (Deritani Nora Lita , Soegiyanto, 2014), efektifitas dalam meningkatkan kebugaran jasmani diperoleh melalui pengembangan permainan tradisional Ekar Mix pada pembelajaran Penjas di Sekolah Dasar sehingga permainan Ekar Mix dapat digunakan sebagai bahan ajar dalam pembelajaran penjas di Sekolah. Fasilitas rekreasi edukatif permainan tradisional Jawa di Daerah Istimewa Yogyakarta (Laksmono et al., 2013) merupakan penekanan nilai kebudayaan daerah melalui nilai pengalaman, karena penerapan permainan tradisional jawa berlandaskan kepada nilai-nilai kebudayaan diantaranya bahasa pengantar, cara, makna, media, dan lokasi permainan.

Penelitian ini memiliki tujuan yaitu merevitalisasi permainan tradisional sebagai wujud sumber daya manusia dalam mempertahankan identitas suatu negara terhadap ciri khas suatu Negara dengan kebudayaan disetiap daerah, fokus penelitian nya adalah revitalisasi permainan tradisional secara khusus di wilayah Jawa Barat. Berbagai wilayah yang ada di Indonesia memiliki jenis permainan tradisional yang menjadi ciri khas suatu budaya sebagai bentuk masyarakat yang memiliki karakter.

\section{Permainan Tradisional}

Permainan rakyat seringkali juga disebut sebagai permainan tradisional, Permainan Tradisional yang ada di berbagai belahan nusantara ini dapat menstimulasi berbagai aspek perkembangan anak, seperti: Aspek motorik : Melatih daya tahan, daya lentur, sensorimotorik, motorik kasar, motorik halus. Aspek kognitif: Mengembangkan imaginasi, kreatifitas, problem solving, strategi, antisipatif, pemahaman konstekstual. Aspek emosi: Kontrol emosi, mengasah empati, pengendalian diri. Aspek bahasa: Pemahaman konsep-konsep nilai. Aspek social: Menjalin relasi, kerja sama, melatih kematangan sosial dengan teman sebaya dan meletakan pondasi untuk melatih keterampilan sosialisasi berlatih perab dengan orang yang lebih dewas/masyarakat. Aspek spriritual: Menyadari keterhubungan dengan sesuatu bersifat Agung.Aspek 
ekologis: Memahami pemanfaatan elemen-elemen alam sekitar secara bijaksana. Aspek nilai-nilai/moral : Menghayati nilai-nilai moral yang diwariskan dari generasi terdahulu kepada generasi selanjutnya (Nugrahastuti, Puspitaningtyas, \& Puspitasari, 2012).

Permainan tradisional yang tercatat dalam Dinas Pariwisata dan Kebudayaan Provinsi Jawa Barat Tahun 2015 sebanyak 44 permainan tradisional. Dalam penelitian ini akan di inventarisir permainan tradisional yang mengacu kepada nilai-nilai kerjasama dan sportifitas yang ada didalam permainan tradisional tersebut, beberapa diantaranya adalah Galah Jidar, Galah Asin, Egrang, Bebentengan, Hong 25, Kelom Batok, Orayorayan, dan Sondah.

Penelitian yang sama di lakukan oleh Dasrun Hidayat (2013) yang dilaksanakan pada masyarakat kampung Adat Dukuh masih menanamkan konsep dasar permainan konclong kepada anak-anak penerus mereka secara re-generasi dengan memberikan pemahaman pola permainan secara jelas agar anak-anak tertarik memainkannya. Warga Kampung Adat Dukuh sangat memegang teguh nilai-nilai yang terkandung dalam permainan konclong dengan tetap melakukan upaya-upaya pelestarian permainan tradisional di tengah himpitan budaya permainan modern. Membangun sebuah paradigma baru di tengah perkembangan zaman yang pesat yang dimaknai melalui budaya permainan tradisional di Kampung Adat Dukuh. Nilai-nilai kearifan lokal pada permainan konclong tetap lestari dan masih diakui manfaatnya oleh anakanak dan para orangtua seperti nilai motorik, kognitif dan nilai-nilai moral (Hidayat, 2013).

\section{Permainan Digital}

Aktifitas yang dilakukan sebagai rasa senang atau menghilangkan kejenuhan yang memiliki aturan sehingga ada yang menang dan ada yang kalah disebut dengan game. Direktur Indonesia Gamer, internet game merupakan sebuah game atau permainan yang dimainkan secara online via internet, bisa menggunakan PC (personal computer), atau konsol game biasa (PS-2, X-Box, dan sejenisnya), game online sebagai permainan yang dapat diakses oleh banyak pemain, dimana mesin-mesin yang digunakan pemain dihubungkan oleh suatu jaringan internet (Febriandari, Nauli, \& Rahmalia, 2016). Game online dapat dijumpai dalam kehidupan sehari-hari tidak seperti pada tahun kisaran 1980-an karena game online hanya bisa di mainkan dengan menggunakan komputer saja (Febriandari et al., 2016). Tetapi saat ini game online bisa diakses menggunakan handpone. Rata-rata saat ini seorang pemain memainkan game online dengan menggunakan handpone dan jaringan internet yang memadai. Di dalam handphone biasanya game online dapat diunduh menggunakan Google Play Store. Di Google Play Store terdapat berbagai aplikasi yang dapat diunduh secara gratis maupun berbayar. Disana seseorang dapat mengunduh atau menginstal berbagai macam game online. Jenis-jenis game online yang sering dimainkan saat ini yaitu Mobile Legend, PUBG, Free Fire, dan AOV yang merupakan game action. Biasanya seorang pemain menghilangkan rasa jenuhnya baik itu dari kegiatan sehari-hari (kerja, belajar, dan faktor lainnya) maupun sekadar mengisi waktu luang dengan bermain 
game online. Tetapi ada juga beberapa pemain yang menghabiskan waktunya berjamjam, bahkan bisa seharian penuh untuk memainkannya dan ada juga yang menghabiskan seluruh waktu jaganya untuk bermain game online.

\section{Revitalisasi Permainan Tradisional}

Kehidupan sesuatu dengan suasana yang ramai disekitar merupakan kegiatan dan aktifitas yang sering dilakukan baik didalam area lapangan ataupun diluar area lapangan, namun jika tempat tersebut telah mengalami degradasi/kemunduran yang dapat dilihat melalui kurangnya aktivitas disekitar tempat tersebut sehingga dibutuhkan kembali upaya untuk memvitalkan suatu tempat/kawasan yang dulunya pernah vital/hidup, akan tetapi kemudian mengalami kemunduran/degradasi. Skala revitalisasi ada tingkatan makro dan mikro. Proses revitalisasi sebuah kawasan mencakup perbaikan aspek fisik, aspek ekonomi dan aspek sosial. Pendekatan revitalisasi harus mampu mengenali dan memanfaatkan potensi lingkungan (sejarah, makna, keunikan lokasi dan citra tempat) (Primayoga Arya, 2015). Revitalisasi sendiri bukan sesuatu yang hanya berorientasi pada penyelesaian keindahan fisik saja, tapi juga harus dilengkapi dengan peningkatan ekonomi masyarakatnya serta pengenalan budaya yang ada. Untuk melaksanakan revitalisasi perlu adanya keterlibatan masyarakat. Keterlibatan yang dimaksud bukan sekedar ikut serta untuk mendukung aspek formalitas yang memerlukan adanya partisipasi masyarakat, selain itu masyarakat yang terlibat tidak hanya masyarakat di lingkungan tersebut saja, tapi masyarakat dalam arti luas (Fauzi, 2016).

Pemahaman terhadap permainan tradisional secara tidak langsung memberikan ruang berpikir bahwa setiap orang mampu dan dapat melakukan permainan tradisional baik di daerah nya maupun diluar daerahnya dengan melaksanakan kegiatan perlombaan dengan tema pelestarian permainan tradisional. Dalam mempermainkan permainan tradisional tidak berpengaruh pada usia karena kegiatan ini telah dilakukan mulai masa anak-anak hingga usia dewasa. Ciri khas permainan tradisional sangat mudah dimainkan, tetapi tetap memiliki karakteristik tersendiri sesuai dengan fungsi permainan tersebut. Misalnya aturan aturan permainan yang dibuat tidak sulit, lagulagu atau nyanyian sangat mudah didengar dan dihafalkan, selain itu juga terdapat variasi dalam memainkannya, serta tidak menggunakan banyak peralatan. Permainan tradisional cukup menggunakan anggota tubuh sebagai peralatannya.

\section{Subjek Penelitian}

Revitalisasi kegiatan permainan tradisional disarankan kepada semua sumber daya manusia disetiap lapisan masyarakat yang bertujuan untuk menghidupkan kembali permainan tradisional khususnya daerah Sunda Jawa Barat, dengan merevitalisasi beberapa permainan tradisional tersebut diharapkan adanya rasa tanggunjawab terhadap pelestarian budaya di Negara Kesatuan Republik Indonesia. Sehingga pada 
akhirnya harapan dari merevitaisasi permainan tradisional pada anak-anak dapat meredam dan meminimalisir aktifitas bermain game online dengan gadget nya.

Sebagai upaya dan usaha tersebut maka penulis telah melaksanakan beberapa kegiatan permainan tradisional dua tahun berturut-turut pada tahun 2019-2020 pelaksanaan kegiatan tersebut melibatkan siswa-siswi se Jawa Barat yang bekerjasama dengan Komite Olahraga Tradisional Indonesia Kabupaten Garut dan didukung oleh Program Studi Pendidikan Jasmani Universitas Garut, Dinas Pemuda dan Olahraga Kabupaten Garut, Dinas Pariwisata Kabupaten Garut dan Kamp Kabupaten Garut, sinergitas ini diharapkan dapat terus eksis dalam menumbuhkan masyarakat Daerah Sunda dalam melakukan permainan tradisional. Sebagai harapan dasar kegiatan tersebut adalah anak-anak mampu mengurangi permainan game online dan beralih ke permainan tradisional sehingga anak-anak kembali kepada fitrah nya sebagai individu yang mempunyai karakter bermain dan dapat berkomunikasi serta beraktifitas sosial dengan nyata di masyarakat. Berikut dokumentasi pelaksanaan pelaksanaan kegiatan festival permainan tradisional yang sudah berjalan.

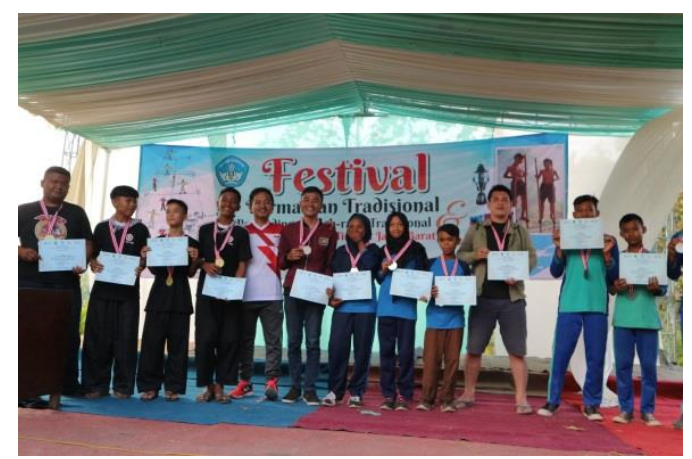

Gambar 1. Festival Permainan Tradisional Jawa Barat 2018

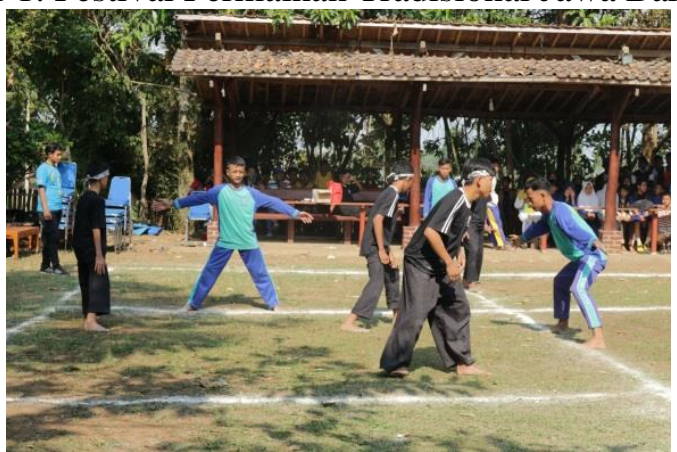

Gambar 2. Galah Sodor 


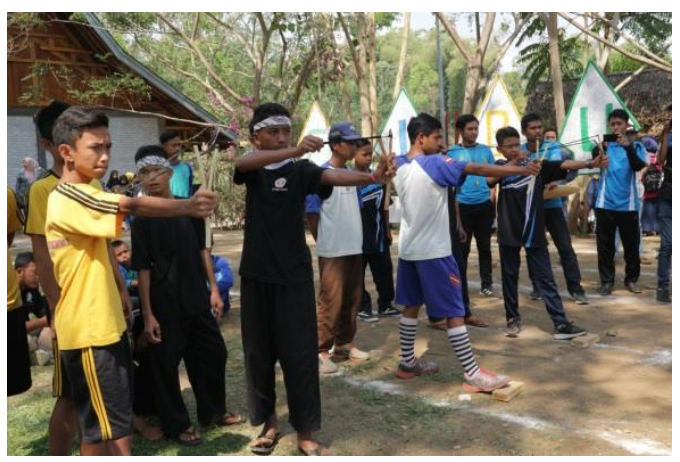

Gambar 3. Ketapel

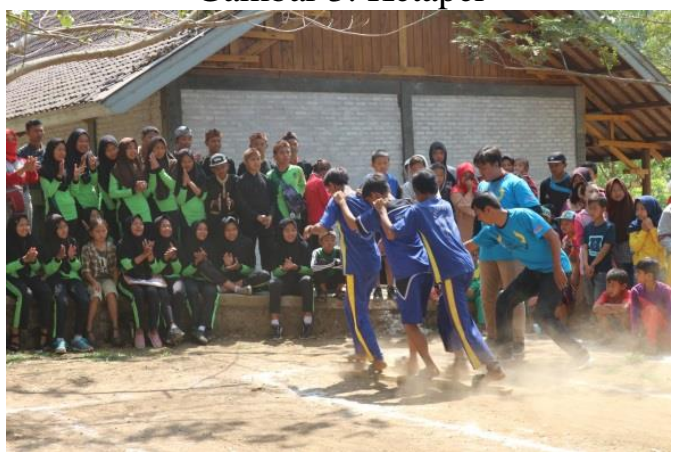

Gambar 4. Tarompah panjang

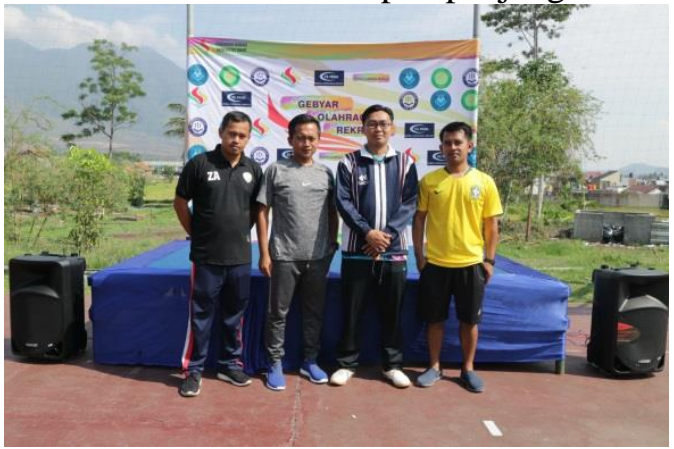

Gambar 5. Gebyar Olahraga Rekreasi 2019 


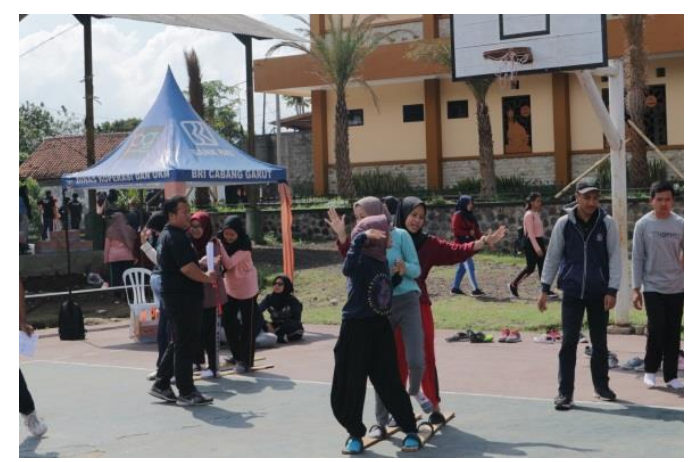

Gambar 6. Bakiak

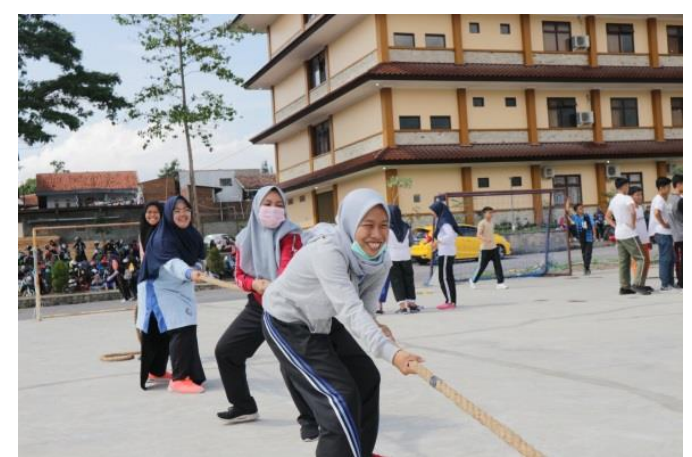

Gambar 7. Tarik Tambang

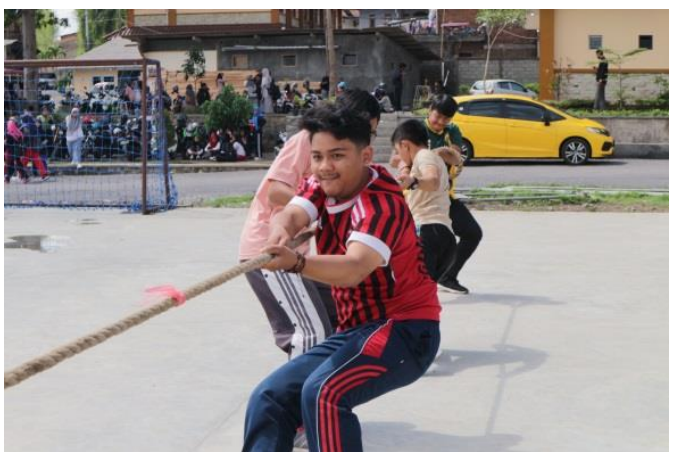

Gambar 8. Tarik Tambang 


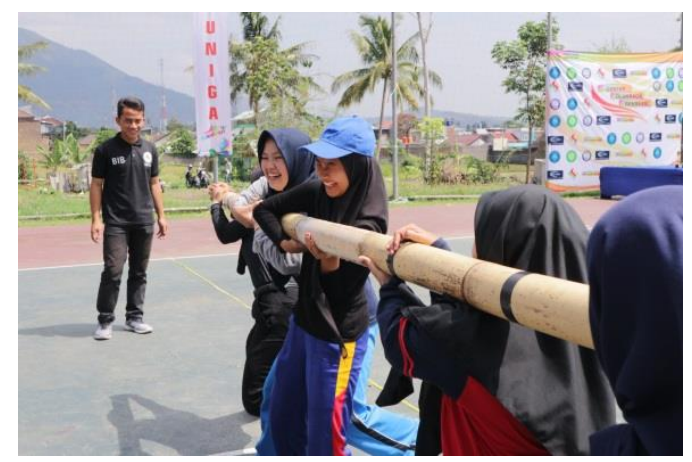

\section{Simpulan}

Gambar 9. Bambu Dorong

Kemajuan teknologi saat ini berkembang dengan cepat sehingga banyak perubahan dalam adaptasi kehidupan manusia bermasyarakat yang tanpa disadari memberi ruang terbatas terhadap kehidupan sosial bermasyarakat. Demikian hal nya yang telah terjadi pada jenis permainan tradisional yang merupakan warisan budaya leluhur dengan berjalannya waktu dan berkembangnya teknologi secara digital maka warisan budaya leluhur kita saat ini bergeser menjadi sesuatu yang lebih modern baik dalam komunikasi maupun interaksi sosial. Penelitian yang dilakukan mempunyai tujuan dan harapan terhadap merevitalisasi kembali permainan tradisional Jawa Barat dengan melaksanakan berbagai kegiatan melalui festival atau perlombaan permainan tradisional Jawa Barat secara berkesinambungan sehingga masyarakat terutama para pelajar dari tingkat dasar hingga tinggat atas mengetahui warisan budaya leluhur nya tentang permainan tradisional sehingga mampu bertahan dan terus diwariskan pada generasi muda selanjutnya.

Permasalahan yang muncul adalah daya saing permainan tradisional terhadap perkembangan teknologi permainan digital sehingga mengikis eksistensi permainan tradisional, untuk menjaga hal tersebut tidak menjadi kerugian dimasa yang akan datang maka penulis ingin menyampaikan bahwa permainan tradisional masih dapat dihidupkan kembali aktifitasnya melalui beberapa kegiatan dengan sasaran utama nya adalah generasi milenial. Aktifitas permainan tradisional mampu bertahan dengan mengembangakan kararakter anak-anak untuk menjadi pribadi dan kelompok yang mencintai, menghargai dan menjaga warisan budaya diatas namun pada generasi milenial saat ini tidak dipungkiri daya tarik teknologi semakin kuat sehingga perlu adanya penanaman karakter kepada generasi milenial dengan menggabungkan manfaat teknologi terhadap keberlangsungan permainan tradisional. Terdapat beberapa cara yang bisa dilakukan dilakukan untuk menjaga eksistensi permainan tradisional dalam mengembangkan karakter anak yang seimbang dengan permainan game online sebagai bentuk perkembangan teknologi diantaranya, orangtua wajib memperkenalkan berbagai permainan tradisional, tidak hanya memberikan fasilitas permainan modern berupa game online, kemudian lingkungan sekolah merupakan media sosialisasi bagi anak-anak yang dapat menyampaikan ilmu pengetahuan tentang permainan tradisional melalui proses kegiatan belajar mengajar atau berbagai 
kegiatan festival yang secara bertahap terus dilaksanakan. Sehingga anak-anak mampu menjadi seorang yang bertahan dalam menjaga eksistensi permainan tradisional agar tidak menghilang dengan perubahan jaman dan moderenisasi yang sangat pesat.

\section{Daftar Pustaka}

Alif, M. Z., Sachari, A., \& Sabana, S. (2015). Konsep Desain Venakular Dalam Bentuk pagawéan barudak, 25(4), 391-404.

Deritani Nora Lita , Soegiyanto, dan S. (2014). Pengembangan Permainan Tradisional Ekar Mix Dalam Pembelajaran Penjasorkes. Http://Journal.Unnes.Ac.Id/Sju/Index.Php/Jpes, 3(1), 42-45.

Fauzi. (2016). Pembentukan Karakter Anak Melalui Permainan Tradisional CimCiman. Jurnal Ilmiah VISI PPTK PAUDNI, 11(2), 99-109.

Febriandari, D., Nauli, F. A., \& Rahmalia, S. (2016). Hubungan Kecanduan Bermain Game Online terhadap Identitas Diri Remaja. Jurnal Keperawtan Jiwa, 4(1), 50-56.

Hidayat, D. (2013). Permainan Tradisional Dan Kearifan Lokal Kampung Dukuh Garut Selatan Jawa Barat. Jurnal Academia, 5(2), 1057-1070.

Irfansyah, U. Q. A. P. (2013). No Title, 124-140.

Laksmono, S., Pembimbing, D., Wonoseputro, C., Studi, P., Arsitektur, T., Petra, U. K., \& Siwalankerto, J. (2013). Fasilitas Rekreasi Edukatif Permainan Tradisional Jawa di Daerah Istimewa Yogyakarta, 1(2), 125-132.

Nisrinafatin. (2020). Pengaruh Game Online Terhadap Motivasi Belajar Siswa. Jurnal Edukasi Nonformal, 115-122.

Nugrahastuti, E., Puspitaningtyas, E., \& Puspitasari, M. (2012). Nilai-Nilai Karakter Pada Permainan Tradisional. Prosiding Seminar Nasional Inovasi Pendidikan Inovasi Pembelajaran Berbasis Karakter Dalam Menghadapi Masyarakat Ekonomi ASEAN, 265-273. Retrieved from https://jurnal.fkip.uns.ac.id/index.php/snip/article/view/8942

Primayoga Arya, P. A. (2015). Revitalisasi Permainan Tradisional Bali Sebagai Bagian Dari Atraksi Wisata Budaya Di Kota Denpasar. Jurnal Master Pariwisata (JUMPA), $1, \quad 83-99$. https://doi.org/10.24843/jumpa.2015.v01.i02.p07

Putu Winda Suyeni ${ }^{1}$, I Nyoman Wirya ${ }^{2}$, P. R. U. (2016). Tradisional Magoak-Goakan 
Untuk Meningkatkan Putu Winda Suyeni ${ }^{1}$, I Nyoman Wirya ${ }^{2}$, Putu Rahayu Ujianti ${ }^{3}$ Fakultas Ilmu Pendidikan Universitas Pendidikan Ganesha e-Journal Pendidikan Anak Usia Dini Universitas Pendidikan Ganesha, 4(2).

Yudiwinata, H. P., \& Handoyo, P. (2014). Permainan Tradisional dalam Budaya dan Perkembangan Anak. Paradigma, 02, 1-5.

http://www.disparbud.jabarprov.go.id/applications/frontend/index.php?mod=objekwisata\&act $=$ showDetail\&catid $=61$ \&page $=5$ (diakses tanggal 16 maret 2021). 